\title{
The Flow of Narrative: Misleading Structures and Uncertain Faiths in Wieland
}

\author{
Justin D. Cosner
}

\section{Misleading Causality}

In the last years of the eighteenth century, Charles Brockden-Brown wrote the first major American Gothic novel, reworking a famous criminal case of arson and murder into a dizzying narrative of mystery, religious fanaticism, and the inexplicable. Beyond these interests in uncertainty, much of the novel's notorious difficulty stems from its fractured narrative, rendering it more a series of set-pieces than a cohesive story. The first set-piece is Wieland Sr.'s solitary temple, built on a hill of the property to which he retreated from religious persecution in Europe, which subsequently recalls the formative imagery of Winthrop's “shining city on a hill”. Yet while there is indeed an inexplicable luminescence in Wieland's temple, it is not that of radiant peace but, in fact, the flicker which preempts a mysterious conflagration, a spontaneous combustion which kills the elder Wieland. This unexplained event, and the temple of lonely meditation which houses it, models some of the complex interactions between belief, uncertainty, and violence in the text, even as the optimistic ideologies of American destiny and Enlightenment progress are called into question.

The novel's Gothic qualities question such totalizing structures as Brown reworked the Gothic form to fit the US landscape and the conflicts inherent to its expansionist and Enlightenment projects. Lacking the castles and cathedrals of Europe and the political or religious controversies which haunt them, Brown defends his alterations, dismissing the "[p]uerile superstition and exploded manners, Gothic castles and chimeras," of European practitioners and instead invokes "incidents of Indian hostility, and the perils of the Western wilderness, [as] far more suitable” subjects for Americans (Brown, Edgar Huntly 3). But despite dismissing chimeras and super- 
stitions, which suggests a skeptic's disenchantment of the Gothic world, Brown's oeuvre manifests a striking, critical approach toward the comfortable rationalist subject. Indeed, supernatural forces and even madness hover at the fringes of civilization and the civilized. Far from evacuating the Gothic of the power of irrational and supernatural forces, Wieland describes the susceptibility of figures of comfortable surety and provokes an acceptance of uncertainty, and the possibility of an accompanying faith, as necessary qualities of openness to non-material values and to others. But the primary way in which Brown's Gothic poses an uncertain alternative to totalizing and concreted structures of certainty comes in the manner of the story's telling, the text's meticulously reconstructed narration by Clara, which clashes with the thematic interest in Gothic ambiguities.

Wieland Sr.'s death left his two children, Clara and her brother, the younger Wieland, each half the property, including that lonely temple which they convert into an outdoor parlor for company and lively talk. But their group's educated society is marred by inexplicable voices, which confuse and concern them as the voices seem to come from impossible distances or absent speakers. Not long after, their group is introduced to a mysterious wanderer, Carwin, whom Clara finds fascinating. The mysterious voices begin to threaten Clara, who twice hears them conspiring behind her closet door, and worse they work upon Wieland Jr., who follows in his father's obsessiveness, albeit one transformed by Enlightenment philosophies. Under what he believes to be God's direction, Wieland kills his family and unsuccessfully attacks his sister, only to be drawn off by the vocalizations of Carwin, who has just told Clara that he is a talented ventriloquist. The novel ends with Wieland being arrested and Carwin admitting to teasing the group with his powers, even using them to move surreptitiously among them, but adamantly denying having given Wieland order or cause to resort to murderous acts. The possibility of Wieland's madness and/or supernatural agency lingers in the text, disputed by the rationalistic family friend, Pleyel, who marries Clara at the novel's close.

For this exploration of certainty, faith, and the supernatural, it is not just important that the novel ends in uncertainty, but also that the attempt to explain away what appears inexplicable is itself actually linked with the most violent and problematic moments in the text. When Clara first rushes to Pleyel after hearing the conspiring voices which are later discovered to be Carwin terrorizing her, Pleyel refuses to believe her on the grounds of the unlikelihood of such voices. He argues that because they are inexplicable they are thus unwarrantable. Later in the book, he again refuses to believe Clara, this time as she protests her innocence of having been with Carwin. Pleyel heard Carwin's ventriloquism imitating Clara's voice, and therefore refuses to question the validity of his, even for the sake of his beloved's protestations. Even more telling of the pitfalls of such certainty is Wieland's justification of the murder of his family, in which he cites his desire for surety, for true knowledge of God's will as the monomania which would end in his murderous rampage. "I have thirsted for the knowledge of his will," Wieland laments, "but my knowledge has always stopped short of certainty" (151). It is because of his rapture in "the supreme delight of knowing," in the perceived command of God, called a "direct communication," an "audible enunciation," that Wieland feels capable and compelled to commit his 
atrocities. It is precisely Wieland's attempt to know divine will with certainty, beyond any measure of self-doubt, which provides the conditions for his being able to do that which self-doubt would certainly forestall. The novel, in this manner, links the impulse for certainty, the desire to erase or dismiss uncertainty, with the very acts of horror described. It is with this in mind, that I propose reading the text's narratological apparatus as coinciding with and illuminating a larger critique of the impulse to certainty and totalizing understanding.

As a means of access to this topic, this paper begins by asking why the narrator, Clara, for so long withholds her knowledge of eventualities in the text's telling-a decision which makes for exciting reading but shows a baffling artifice on her part. Clara narrates the events after the fact but spends much time imparting her past ignorance when the future events are known to her. Some have suggested that Clara withholds the facts of the story in an attempt to impart a feeling toward the story, enlisting the reader's sympathy and casting Carwin as the villain. "Clara repeatedly asseverates Carwin's responsibility for the destruction of her family," Marcia Nichols writes, "but instead of enlightening the reader, she chooses gradually to reveal the unsavory elements of Carwin's character... prepares the reader to accept Carwin's guilt without having adequately proved it” (463). Alternatively, and according to Anthony Galuzzo, "Clara does not present us with an exact summary of the story about to unfold so much as she evokes terror by way of deliberate obscurity" (262). Still others read Clara's narrative strategies as a product of her own mental instability, perhaps even insanity (Russo 60). Instead of these arguments, I suggest Clara's narrative logic is part of a larger structure of understanding which the novel illuminates and, ultimately, critiques - that is, an Enlightenment faith in causal chains, reciprocal effect, and an untainted translation of motive to destiny. Clara believes that events follow logically, from rational choices, and predictably toward their inevitable conclusions. I further suggest that the generic protocols of the Gothic, such as ineffable motivations and inexplicable consequences, coincide with a sense of radical openness to possibility as an alternative posture towards the world and to others, which contrasts with this strict Enlightenment causality. As Galluzzo indicates, and despite Clara's attempt to perfectly replicate the events as they corresponding to her discoveries, "Wieland famously leaves the reasons for the eponymous character's horrific murders ambiguous, along with the "spontaneous combustion" that initiates Clara's tale ... These incongruous mixtures of style and genre attest to a more complex process of literary appropriation on Brown's part” (262-263). It is my contention that these "incongruous" stylistic elements of the novel arise from an active attempt of the narrator to impose a clear, logical, and chronological template over events which resist such determinations.

A crucial attribute of my argument is that Brown's novel performs and encourages an uncertain Gothic sensibility, an openness to the inexplicable and an acceptance of the unknowable, more than any particular viewpoint voiced in the novel's transcribed debates. Jane Tomkins has focused on the historical controversies raging in postrevolutionary America, and accounts for Wieland's strange mixture of elements as a clear indictment of certain Post-Revolutionary politics, particularly the dangers of social mobility and erasures of class markings. Tomkins likens the novel to "a politi- 
cal tract" which depicts an "uncharacteristically negative view of what it meant to survive the War of Independence,” (44) specifically citing the wandering Carwin as preying on a culture "in which the insignia of social stratification have been stripped away in the name of equality" (52). Tomkins notes Brown's defense of fictionality as a means of public edification, in a letter accompanying a copy of the book sent to Thomas Jefferson, and Brown's "notions of how writing fiction might change national opinion” (46). Unsurprisingly, Tomkins sees Brown's comments on the text's "usefulness" as stemming from a specific stance and contribution to the ongoing debates of Post-Revolutionary America, suggesting that Wieland's "meaning would be clear to his readers, since the usefulness of his book would naturally depend on its being understood" (41). But rather than trying to untangle the baffling events of the novel with the assumption that they contribute to a cohesive and specific political position, I suggest that the novel's dizzying affect and the fictionality which Brown employs is useful as a means of conditioning readers into a position of uncertainty, and a self-reflective, even humble, questioning of Enlightenment modes of accounting the world. The Gothic fictionality, in this manner, is not important as a more effective means of building toward a rationalistic position but rather a method of expanding questions outside of causal certainty.

The quality of rationalism critiqued here is primarily sketched out in Clara and her companions, indeed even serves as a topic of discussion, and is characterized most often by the concept of "flow" in the text. The term flow, and related ones like "chain," "train," and "series", are used with almost neurotic constancy to describe the connections between precedents and antecedents, defining the actions of the present in terms of past inertia and predicting the future with prophetic surety. Likewise, these terms feature heavily in the long, pregnant passages regarding the drift of consciousness in the interior life of the narrator. Clara's narratalogical retention of the facts is emblematic of a commitment to an Enlightenment sense of perfect continuity, which would justify Clara's dogged attempts to reveal events only in their original sequence. While it is ostensibly the vocalizations of Carwin that "mislead" the characters of Wieland, it is Clara's attempts at organizing events that produce the misleadingly certain account of the story. Ultimately, Brown's novel gestures toward the need for a more unstable model of narrative which could accommodate the problematic ambiguities that remain despite the imposition of a rigidly causal and chronological narrative.

In a relevant study of paranoia and conspiracy theories in this post-revolutionary period, Gordon Wood has shown that it was common among “'reasonable people,' indeed the most enlightened minds of the day-to believe in malevolent conspiracies" (409). Wood clarifies that the "belief in plots was not a symptom of disturbed minds but a rational attempt to explain human phenomena in terms of human intentions and to maintain moral coherence in the affairs of men" (429). Ultimately, the belief "flowed from the scientific promise of the Enlightenment" but also, "represented an effort, perhaps in retrospect a last desperate effort, to hold men personally and morally responsible for their actions” (411). It is this sensibility at work in Clara's plotting of the events which is critiqued via Brown's Gothic uncertainties. Wood's historical study even finds nonfictional writing of Brown's, from the year following Wieland's 
publication, which reveal Brown's specific resistance to this paranoid impulse which attributes tragedy to causal chains of human intention. The problem being that such thinkers "'assume that all the disastrous consequences were produced by certain individuals and were "foreseen and intended.' To avoid such simple-minded conspiratorial beliefs, wrote Brown, we must be 'conscious of the uncertainty of history' and recognize that 'actions and motives cannot be truly described,' for they are not always integrally related" (436-437). This uncertainty and indescribability is evident in the Gothic ambiguity in Wieland which clashes so startlingly against the attempted reconstruction by Clara.

Clara's invasive structuring of events also coincides with theories of narrative and the way stories reflect back on their telling, proving to be metaphors of their own interest in articulation. Peter Brooks suggests that in story-telling, "the incomprehensible metaphor of transmission" must be "unpacked as metonymy" (26). That is, story-telling as a means of exploring the relation between the telling and the expressed, cannot have recourse to a simple metaphoric correspondence but must be revealed in the small, step-wise, metonymic movement of plot. This characterization seems to fit Clara's methodical commitment to chronology, insisting that we can only understand the "meaning" of what happened to her by following her through each step. The sequencing of story, its plotting out, Brooks claims, more than its central themes and symbols, provide access to a story's most salient interest: the final closure of meaning, which an ending bestows. Brooks asserts that, "it is important to pursue the notion of desire as that which is initiatory of narrative, motives and energizes its reading, and animates the combinatory play of sense-making” (48). I quote Brooks at length to suggest how Clara's desire in plotting, expressed in a carefully recreated simulation of her own gradual understandings, is not to unpack or interpret what happened but precisely to impose a "sense-making" on the narrative. Clara, as opposed to Carwin whom I will touch on later, is not a reader of the events but a writer, not interpreting but fitting them into a pre-formed rhetorical mould. This rhetorical sense-making, which will also be considered in its own right, comes highly suspicious in a text so riddled with irrationality and an implicit critique of the desire for pure-truth. Brown's violently disruptive Gothic undermines the rigid plotting, confuses even the most carefully constructed chronologies, and likewise insists on the need for uncertainty in the end, a doubt of oneself and the self's capacity for totalizing knowledge. But the text insists, nonetheless, on the need for keeping faith in each other and in the capacity of narrative to render meaning despite the limits of its construction — so that even as faith turned to certainty is shown to be murderous, faith based in uncertainty holds the possibility of keeping a vigil for meaning without the danger of imposing mastery.

\section{Unerring Flow}

The novel's opening features the purposeful aim of its narrator with Clara's claim that her story will "exemplify the force of early impressions, and show the immeasurable evils that flow from an erroneous or imperfect discipline" (5). This is the first example of a "flow" in the novel, and in the first paragraph no less. And indeed we 
get a sense of Clara's own early impressions and her reasons for believing in their primacy in a description of her father. His religious belief looked to originary sources, even built on the liquid metaphor of "flow", by calling the Bible the "fountain, beyond which it was unnecessary to trace the stream of religious truth" (8). And just as the father imagines his divine calling of missionary work as flowing unerringly from this source, so does he eventually imagine his death as an unavoidable end after his perceived failures as a religious emissary to the Native Americans (12). Though the father's individualized faith might be seen as an encouraging resistance toward totalizing religious expressions, the impulse toward proselytization suggests that his expression too was totalizing in its own fashion.

After the father's spectacular death and the religious fanaticism which characterized his life, his children appear to choose a different ideological posture toward the world. The father's temple of lonely meditation has been made into a "joyous" (22) space of society and of intellectual and rhetorical praxis, complete with a bust of the master rhetorician, Cicero, at its center (22). But the inescapable teleologies of the father's belief linger in his temple, and his children recreate his sense of the primacy of originary sources and fated destinies in their own world of reason, rhetoric, and Enlightenment surety. The first debate we are privy to among this enlightened foursome hinges upon this very concern. Pleyel declaims Wieland's argument, citing a wrong Latin translation as the source from which Wieland moves and thus invalidating all of his following claims (28). And of course,"[n]othing," says Clara, "would decide the contest, but an appeal to the volume” (28), further illustrating the group's understanding of veracity as modeled by the idea of truth necessarily flowing from an originating source.

Among this group, Wieland is described as governed by "moral necessity and Calvinistic inspiration" and it is not surprising that he too saw his "father's death [... as] flowing from a direct and supernatural decree" (33, my emphasis). Later in the novel, after Wieland has murdered his family in accordance with what he believes is a divine mandate, we hear his court arguments in his own defense. Wieland recreates the flow of his thoughts for the court, insisting that "the series of my thoughts are easily traced" (152); and like his father before him, he sees God's mandate as the worthy "source" (152-3) from which his inspiration comes. Citing the worthiness of his source in his father's God, and the natural, easily followed flow of his thoughts, Wieland believes his final actions-nothing less than the murder of his family- to be beyond reproach.

This sensibility, though not the murderous end, is echoed in Clara's writing as she too attempts to piece out the flowing movement of her thoughts and the story itself, as a means of justifying her vision of understanding. And just as her brother and father insist that God is the fount from which good flows, so does Clara admit that incalculable "evils may flow from the consequent deductions and understanding" (33, my emphasis) of depraved senses. What is more, we see this conceptualization of "flow" in Clara's thoughts, as she self-consciously ponders over her musings, wonders at how they give way to each other, a veritable steam-of-consciousness. "So flexible, and yet stubborn, is the human mind" she remarks, only to describe its function as "unalterably observant of the direction given to it" and to lament that begin- 
ning on the first "link" leads one inevitably down to a "termination of that chain" (50). But Clara's confidence in perfect continuity and her belief that events will inevitably yield to their fatal result, called the "paranoid style" by Wood, seems to be highly problematic as it also includes, like her father, a sense that actions follow intentions and thus eventualities can always be traced to early mistakes. In a now famous line Clara admits that she "used to suppose that certain evils could never befall a being in possession of a sound mind" (61). This sort of logic follows from what we observe in the enlightened foursome and serves to set "a sound mind" as the greatest protection a person can secure.

In a significant moment, discovering that the voices in her closet were Carwin tormenting her, Clara's impulse is to resist the chaotic nature of her mind. "Order" she laments, "could not readily be introduced into my thoughts" (85) until she concentrates to "give a slower motion" and to "regulate the confusion" (86). Clara's faith in things flowing from their source toward their inevitable end give her the sense that "ordering” her thoughts, "regulating” them, will yield purity of understanding. This concept is a through-line in the major characters of the book, and seems to be Clara's justification for retaining the facts of her story until their occurrence in the chronological order she so assiduously maintains. Just as Clara must "order" her thoughts, "regulate" them to bring about an understanding of the events and their continuities, so does she order and regulate the flow of information to the reader, such that we understand events as she did, never knowing what is to come as she does in the moment of writing, but anchored always to her ignorance at the time of the story's occurrence. Brooks suggests plotting and narration of events in story are driven by a human psychological "need for ordering" (xi), that plots are "explanatory narrative" which seeks to establish origins and continuity with the past (6). And this seems to bear out in Clara's construction of the story out of these events. But we must recognize the problematic implications of Clara's project-it is not just continuity with the past that plotting establishes but also a platform for the eventually concreted meaning in the end.

The praxis of establishing a basis of credibility from which to draw claims is an important topic in Wieland, particularly because Brown studied Law before becoming the country's first novelist. And the story seems to register the difference between fictionality and rhetoric, at least implicitly, with rhetoric being the favored practice for the group's entertainment. Clara admits much respect for rhetoric, applauding Pleyel, whose "narratives were constructed with so much skill [... that things] least entitled to credit, were as yet rendered probable by the exquisite art of this rhetorician” (68). Given this respect of rhetoric, and Clara's explicit claim at the outset that the story will "exemplify" her point, it is tempting to view Clara's narrative strategies as a rhetorical, rather than novel-esque endeavor. And indeed her own rhetorically motivated narrativising is confirmed at the novel's close, as she reveals a purposeful trajectory; "all that I have said is preparatory for this scene" she claims after the climactic scene where Carwin's ventriloquism calls off Wieland. And just afterward she gives the moral of her story, illustrated by a side plot: virtue becomes the victim of treachery, but only "owing their existence to the errors of the sufferers" (223). She suggests that should Wieland have begun with "juster notions of moral duty, and of 
the divine attributes" or she been "gifted with ordinary equanimity of foresight, the double tongued deceiver would have been baffled and repelled” (224). Clara's narrative logic insists that things flow predictably from their source and thus knowing the source or the destination, one may reconstruct and understand the sequence of events. Not only does she organize the narrative to move unerringly according to her rhetorical vision, her vision is itself about the importance of locating the source and destination of narrative. In essence, we might argue that Clara is not telling the story of her experience at all but rather trying to prove an argument about her experience via the careful plotting.

But despite the concerted intentions of the narrator, the text moves subtly to undermine this sort of concreted logic. Carwin serves to show that Clara's faith in cause and effect, motive and action, are fundamentally flawed. Steadfastly denying having called Wieland to murder, Carwin still apologizes for his cruel and manipulative ventriloquizing, saying, "I have acted but my actions have possibly affected more than I designed" (179). He goes on to admit that he acted "without malignant intentions, but without caution" (181). Later he will wonder at the series of events, asking how his acts could "set in progress the machine" (197) of such horrors. While Carwin vocalizes a resistance to the notion that consequences flow from a motivated source, Wieland's protestations of innocence also undermine the reasonableness of Clara's model by showing its logic taken ad absurdum. We are told in the beginning that an aim of his intellectual curiosity was "to settle the relation between motives and actions" (22) and in the end, after Carwin informs Wieland that he is not acting on divine orders, Wieland claims, "[i]f I erred, it was not my judgement that deceived me but my senses. In thy sight, being of beings! I am still pure. Still will I look for my reward in thy justice” (205). Clara speaks our outrage at this twisted reasoning, shocked that he found "consolation in the rectitude of his motives" (205), even if she fails to realize her ideological complicity to this logic. Essentially, Carwin and Wieland both deconstruct Clara's belief in motivations determining effects: Carwin by suggesting events far exceed his intentions, Wieland by suggesting that good intents justify all their repercussions.

The novel ends with no resolution of its mysteries but does so, instead, with Clara's assertions of the story's moral, that all tragedies can be reasonably traced to mistakes, and with Clara's marriage to Pleyel. And like the imposed meaning, stamped over the problematic fissures, Clara's marriage also smacks of a forced reconciliation. Pleyel, long described as the most skeptical with regard to the unknown in an already skeptical group (23), failed twice to believe Clara in her time of innocence and need, choosing both times to side with his reasonings instead of crediting the implausible. And at the end, Pleyel maintains still that all of the events can be understood logically, despite the deep inconsistencies of the text. That Clara chooses to construct and understand the story according to the rhetorical praxis of the brother who justifies his murders, and the lover who fails to have faith in her own torment because of its supernatural overtones, seems to reiterate the importance of an alternative though it goes mostly unspoken in the tightly controlled text. While Clara's narrative strategies and the Enlightenment ideologies which bolster them comprise the matrix of concreteness and fanatical surety in the text, the Gothic uncertainty seeping 
through and a sense of faithful openness exist alternatively.

This alternative, an alternative posture towards those things unaccountable, seems best modeled in Brown's Gothic. It provides a sense of dimness to vision, as the Gothic is want, and an air of uncertainty with regard to knowledge of the material or the divine. But more important perhaps, it begs an openness to both, a willingness to self-reflect, pause in uncertainty and accommodate one's self to imperfect knowledge even as we strive to understand. It could also stretch to cover the sort of faithful credit to persons which fails in the text, as in Clara's treatment of Carwin, and Pleyel's treatment of Clara. It is precisely the power of the Gothic, Brown's Gothic especially, which looks to condition its readers into a sense of this humbleness before the irreducible complexities of the world, the unaccountable vagaries of fate, and the dangers of a position of mastery over narrative and understanding.

\section{Uncertain Faith}

Before this final section, it is important to clarify the terms "Gothic" and "faith" in this study with regard to their historical contexts, insofar as it is possible and to the purpose of the inquiries here. The term "Gothic" is most relevantly defined as aesthetically "belonging to the dark ages" as "opposed to the classical” (OED). As such, its narrative associations are often the mystical, excessive, and romantic instead of the staid and systematic. The Gothic genre has long been characterized by its own internal frictions, evidenced by the difference in its eighteenth century originator, Horace Walpole, and its most popular producer, Anne Radcliffe. While Walpole's The Castle of Otronto (1764) languishes in fantasy and the supernatural, Radcliffe's novels helped develop the subgeneric strain of "the supernatural explained," where all mysteries eventually prove to be materially accountable. Brown's work in literary magazines evinces his fluency with both sides of the genre, his vocal involvement in the debates of its artistic merit, and its possibly "dangerous system of morals," though Brown's most pointed criticisms seem to fault the genre for derivativeness more than danger (Cody, 117). W.M. Verhoeven has noted in Brown a tension between the scientifically sound and the supernaturally explorative Gothic, apparent in diary writings where Brown brainstormed novel ideas:

[I]n the diary he lists 'Miracles. Events produced by divine agency', among which he mentions: 'Conception'; 'Contravertion of gravity'; 'Revival'; 'Turning water to wine'; 'multiplying food'; 'Healing frenzy'; 'Restoration of life'; 'prescience'; and 'omniscience'. Although these manuscript jottings are well-known, I mention them anyway because they throw into relief the fact that Brown, a 'pupil of Reason' according to his friend Elihu Hubbard Smith and a devotee of Godwin's creed of 'rational anarchy', if there ever was one, should be so attracted to issues and phenomena that seem to go beyond the rational and the known. (Verhoeven 95)

Given the elusive nature of Wieland's mysteries and Brown's interest in both the cosmically and the materially determined Gothic topics, it would seem that the Gothic functions for Brown as something closer to what Tzvetan Todorov has called "the 
fantastic," that narrative form which "occupies the duration of ... uncertainty" with regard to either a natural or supernatural account of their events (25). That is, for Brown, the Gothic didn't serve as a space to float theories of the cosmic world, nor did it serve to conjure specters for the sole purpose of proving them to be parlor tricks; instead, the Gothic became a site of conscious and prolonged uncertainty, an exercise in resisting determinations.

Brown's engagement with systems of faith is also fraught in the period surrounding his prolific output of fiction and perhaps landed him among a slightly different kind of duration of uncertainty. The early 1790s saw Brown at his most engaged with Godwinian rationalism and antistatism but the late 1790s of Wieland's writing falls between this "free-thinking” period and Brown's religious turn, expressed in magazine editorial writings in 1803, calling himself a "champion of the Christian religion” (Cody, 26). Rather than pinpoint a dramatic moment of conversion, or a shift in self-promotion, it seems more likely to imagine Brown, like so many before and after him, to be actively grappling with questions of faith and doubt over the course of this period. Granting that, his choice of Gothic mode in Wieland, neither definitively supernatural nor exhaustively explained, seems to coincide with a faith in the numinous that was itself neither fully denied nor accepted. It is this sense of Brown's uncertain Gothic and a corresponding sense of openness to, but not concreting of, faith that I propose to be operant in Wieland.

Unlike the deeply entrenched and more clearly defined Enlightenment causality of Clara, the characterization of this alternative posture of uncertainty persists in the novel, evoked not by the flowing sequence of events which Clara details, but by the uncertain gothicism which undermines them. Carwin's character, considerations of differing religions, and a depiction of faith in elusive but immanent meaning, all contribute to this alternative ideological posture. Helpfully, much critical attention to Wieland has turned on Brown's ambiguous relationship with religion and the novel's seemingly contradictory depictions of skepticism and belief. While critics such as Marshall Surratt describe a religiously committed Brown, taking at face value the author's description of himself as a "champion of the Christian religion” (311), it seems nearly impossible to square this with the novel's violent depiction of fanaticism and religious dogma. Michael Gilmore, with perhaps more nuance, suggests that Brown had a very mixed, sometimes antagonistic view of religion (108) but nonetheless regards Wieland as a "retelling of the fable of the fall of man" (107). Gilmore pursues this interpretation as a means to investigate Calvinistic and Catholic impulses among the characters and suggests that Carwin's Catholicism and "curiosity" bring an end to the edenic society of the enlightened foursome. This framework is helpful to my interpretation, but for different reasons than those Gilmore describes. In considering the novel's concern with "knowledge", specifically the "knowledge of good and evil" whose pursuit precipitates the fall, my reading would reverse Gilmore's such that it is not Carwin's Catholicism and literary curiosity which are figured as the danger but, in fact, the surety of knowledge in Wieland's group which causes their destruction.

This framing of "the fall" as precipitated by the allures of surety is figured dramatically in Clara's sleepwalking dream near the cliff on her property. "I thought I 
saw my brother," Clara recalls of her dream, "standing at some distance before me, beckoning and calling me to make haste. He stood on the opposite edge of the gulf. I mended my pace and one step more would have plunged me into this abyss" (5758). Here, literally, Clara is being tempted towards a fall by the vision of her brother whose encouragement is to "make haste". This impulse for direction, and impatience for reaching the goal, is reminiscent of what has already been observed in Wieland's quest for religious certainty. It is Carwin, hidden at the spot where Clara stands at the edge of the precipice, who calls to her "Hold! hold!" and saves her from the fall. This remonstration anticipates Carwin's intervention in the climax, where Wieland attacks Clara with just such religious zeal, when Carwin's voice "burst from the ceiling, and commanded him-to hold!” (211). In both cases, Carwin's direction to "hold" stands in opposition to a desire to progress, which is consequently linked with the brother and his desire for certainty. Elsewhere, impediments to forward progress are connected to Carwin as Clara demands of him surety, a flow of clear answers as to his accountability: "Thou falterest" she accuses, "faltering is ominous; say yes or no: one word will suffice” (200). It makes sense, given the picture of Clara's dedication to linearity, progression, and certain answers illustrated above, that Carwin is alternatively linked to a faltering uncertainty which resists and disconcerts the group. The scene of Carwin saving Clara at the edge of the cliff is significantly laden with images of ambiguity, not the least of which are brought about by Carwin's voice being thrown impossibly. Unable to "distinguish between sleep and wakefulness" Clara "cannot estimate the time, [...her] faculties were still too confused and the darkness too intense”(58). As with most of Carwin's scenes, here it is the dimness, ambiguity, "the state of uncertainty" (59) which is most notable.

Carwin's associations with this hesitating uncertainty and his central role in the mysterious or ambiguous moments of plot make him the character most associated with the fantastic. And indeed, Carwin's contributions to the plot seem almost always to prolong our doubts with regard to causes rather than to illuminate. This unaccountable uncertainty contrasts with Clara's attempts at rigid plotting in the novel, and likewise connects to different ideologies of surety. This is visible in the differentiation of Clara's companions as mostly rationalist and Calvinistic, wherein one's election is always already certain, compared with Carwin who is markedly Catholic, which carried strong associations with excesses and passions in Gothic literature, and his associated with art and literature. Gilmore goes so far as to describe an "oppressive theological temper of Brown's tale” whose "explicitly Calvinistic bias [...] stamps Carwin as one of the damned” (108) because of his Catholicism. But Carwin's Catholicism, which might be seen as idolatrous and excessively ornate to Protestants, overlaps with the description of him as an enjoyer of literature, a description seeming to set him out as distinct among the group. Despite Catholicism's marginalization, criticism shows the persistent "sensory or mystical appeal of the Catholic church" (Elbert 115) in Gothic literature even among Protestants into the nineteenth Century. The difference between the literary Catholic and the more rhetorically interested Calvinists is figured in their approach to what is now termed the humanities. Elder Wieland filled his hours with duties which "were laborious and mechanical [...] they withheld him from paths more flowery” (7). Most importantly 
he "entertained no relish for books, and was wholly unconscious of any power they possessed to delight or instruct" until he stumbled upon devotional and religious texts which he accepted as fact and constructed beliefs "formed on a narrow scale" (7-8). His temple was built "without seat, table, or ornament of any kind" (11) and though the younger Wieland will take up pleasures in that same temple, in "his studies, he pursued an austerer and more arduous path. He was much conversant with the history of religious opinions and took pains to ascertain their validity” (21).

This austere and rigid search for religious validity, figured by the solitary temple and reflected in the Calvinistic tenets of the group contrast to the description of Carwin who "devoted himself to the literature and religion" (62-63) of his adopted Spain. While selfish and even occasionally cruel, Carwin's actions are tied to a "passion for mystery" (184) which seems to extend or coincide with his religious allegiances. Clara describes her groups' view of Catholicism with regards to education saying it "was not easy to reconcile his conversion to the Romish faith with those proofs of [his] knowledge" (63). Gilmore suggests that Carwin's Catholicism, in contrast to the Calvinism of the text, is linked to gothicism itself (109). Consequently, whereas most of the characters' religiousness is tied to fact, nonfiction, and rhetoric, the text's alternative sees a faith animated by uncertainty and flourishing in a literary sense, even a Gothic one. Carwin's actions as the savior of Clara, as well as the reader's disquiet at Clara's marriage to Pleyel, who had just before refused to credit her testimony with anything resembling charity or faith, seem to undermine Clara's explicated goals of plotting out the story to serve her moral vision. Carwin's connections to literature, and the Gothic qualities his mysterious persona bring to Clara's narrative both help to provide a contrasting sensibility to the text, a sensibility which might be described with less tenets and certain dogmas, and more faith in the face of uncertainty.

In addition to his rootless wandering and his suspect religion, Carwin presents something of a paradoxical picture to the group, marrying "the rustic" and "the advantages of education" (47). Clara ponders over this strange combination, and without irony, attempts to capture "the radiance inexpressibly serene [...] which it would be vain to describe" in "a sketch upon paper" (49). This sequence is telling due to the dramatic discrepancy between Carwin's mysteriousness, his associations with art and literature, and Clara's desire to capture and codify that very expression. These associations with fictionality serve as open possibilities in Wieland which express resistance to Enlightenment surety, rhetoric, and Clara's flowing, linear plotting. Fictionality is so important in the text because the characters who resist it's openness perpetuate the problematic concreting of possibility into closed and reduced systems or, as Thomas Koenigs suggests, they dissolve possibility into probability. Koenigs reads Wieland as an investigation of pedagogical methods, illustrating the foursome's view that effective "pedagogy depends on the actuality of the model as opposed to a "phantom” of fiction” (726). Thus for Koenigs, "Pleyel's probabilistic thought fails for the same reason as Theodore's belief in supernatural intervention: it fails to respect a degree of uncertainty [.... both are] shown to be susceptible to epistemological error due to a failure to think possibilistically” (731). I agree with Koenigs's here and with his further claim that Brown forwards "skepticism of our ability to know 
anything with certainty" yet still maintains that "epistemological uncertainty should not hinder us from attempting to discover truth, or paralyze us with inaction, but it should be kept constantly in view to inform our actions, so that we aspire to get as close to certainty as possible" (728). But rather than seeing this as purely a question of pedagogy, it is also seems a question of faith, of a faith comprised in part by doubt but animated by aspirations for truth, pursuant of meaningfulness but resistant to mastery over meaning. Carwin's function in the plot, his Catholicism, his associations with the Gothic, all orient him away from the reductive praxis of Enlightenment causality but not away from the pursuit of understanding. It is in this manner, that the text's concerns with faith operates like Todorov's fantastic, suspending the reader between accountings, conditioning an acceptance of the limitations of knowability, but still inviting investment in the process of discernment.

This idea of being driven by a desire for broader truths with the understanding that concrete understanding is impossible is one of the ways in which faith has been defined —attending to a hope for transcendent meaning without ever seeing it solidified. Jacques Derrida has written sensitively of faith at the limits of knowledge, in openness and "indecisive oscillation ... between revelation and revealability ... between possibility or virtuality of the event" (68). Likewise, and crucial to the concerns of faith in Wieland, this uncertainty is linked to the openness to difference and otherness. Derrida asks if "[r]espect for this singular indecision or for this hyperbolic outbidding between two originarities, the order of the 'revealed' and the order of the 'revealable,' is this not at once the chance of every responsible decision and of another 'reflecting faith,' of a new 'tolerance'?” (68). This uncertain faith is made necessary by the gap between the hoped for, desired truth and the capacity of human knowledge to ascertain or of language to describe. Carwin's person is significantly described as "incomprehensible [...] such as no human mind can unravel" (120121). And though his actions are often incorrect and sometimes cruel, the disruption his difference brings to the text is essential, as is the alternative questions his character figures with regard to the search for understanding. Robert Hughes locates this concern, suggesting that Wieland pursues a question of ethics and meaning in the language at the limits of signification (65), a methodology akin to Derrida's. And Hughes insists it is Carwin who comes closest to speaking "truth only [...] through false impersonation" hinting at "the specific ways that literature can speak truth to us in ways distinct from the truths of scientific, philosophical, or (one might suppose) divine intercourse” (Hughes 73). My reading of Carwin's Gothic associations, which press the limits of signification, would go further to suggest that these ethical, moral, and epistemological borders, these "limits," which the story plumbs, require a sense of faith and faithfulness as necessary components to bridging the gap acknowledged to exist between an aspired to meaning and a limited expression. Brown's overt claims of the story's didactic purpose coupled with the pronounced short-comings of Clara's methodical attempts at concreting just such an explication, illustrate precisely this need.

The slippage between traditional terms of faith and faith as an ethics of openness emerges in terms precisely associated with certainty in the text. When discussing the possibility of divine direction, it is Carwin who cautiously suggests that a supernatu- 
ral access to divine truth is not impossible; while Clara admits that theories of divine communication were "heard by [her] with contempt" (68). Likewise, Pleyel "scrupled not to deny faith to any testimony but that of his senses" (69) as far as his opinions on the voices went and didn't allow alternative facts "to mould his belief, but merely to give birth to doubts” (69). Significantly, and in Clara's own words, Pleyel is "precipitate and prone to condemn" those who believe differently (109). The alternative faith implied in the text's Gothic uncertainty doesn't just help to imagine that ineffable truths exist though they may not be described, it also anticipates an ethics of acceptance which would accommodate others and otherness in ways which the surety of the novel's central characters fail. This is echoed in Derrida's exploration of faith at the limits of knowledge, which grounds "a new 'tolerance'”(59) and also in thinkers like Emmanuel Levinas, whose work "propose[s] to describe ... a relationship with the other that does not result in a divine or human totality, that is not a totalization of history but the idea of infinity" (52). This infinity counterposes the impulse to totalization and mastery and instead sees the other as "beyond the capacity of the I" (51). Brown's Gothic uncertainties obviously prefigure those of Derrida and Levinas but nonetheless caution against the same surety born of singular perspectives and of totalizing systems.

To finish on this note, I will return to Clara's methods and this surety which manifests itself most problematically as a sort of closedness, against which the open, faithful, uncertainty contrasts. The stakes of this closedness are not just seen in ungenerous condemnations and contempt but also in hopelessness and resignation. Clara declares early that the "sentiment which dictates [her] feelings is not hope" (5) and intimates that all events must ultimately culminate in death, the final closure. Clara's sense of events flowing determinately from their source toward their inevitable conclusion, and the hopeless sense of meaning as a closure which only death can complete, again coincides with Brooks's narratological work. Brooks argues that a text is driven by this ultimate telos towards its finale and "[o]nly the end can finally determine the meaning, close the sentence as a signifying totality” (22), which is why narratives must "imagine in advance the act of transmission, the moment of reading and understanding that it cannot itself ever know, since the act always comes after the writing, in a posthumous moment” (34). In Clara's view of closed possibilities and fatalistic meaning it is unsurprising that she sees death this way, as the only ending.

The sense of a singular religious destiny, the concreting of meaning in rhetoric, and the final closure of death are all tied together in the climactic ending scene. Clara writes of the climax that this "is the spot which I have chosen in which to breathe my last sigh,” asking just before “[h]ave I not fulfilled my destiny?” She follows through on her original metaphor of flowing eventualities stating, "I care not from what source these disasters have flowed; it suffices that they have swallowed up our hopes and our existence” (213). The duty of writing and the sense of unavoidable death occupy the last lines of the narrative before the final retrospective chapter: "and now my repose is coming - my work is done” (214). Here, the text most explicitly contrasts a living uncertain faith with a stifling and deadly certainty, suggesting of the later that such views are not just oppressive, as with Wieland's crime, but also hope- 
less. As Wood writes of the eighteenth century impulse to causally attribute all tragedy to intention, the "conspiratorial interpretations of the age were a generalized application to the world of politics of the pervasive duplicity assumed to exist in all human affairs” (427). Alternatively, Brown's ambiguous Gothic cautions this mastery of knowledge, even as it anticipates a generous and hopeful ethics which might exist in uncertainty.

\section{Works Cited}

Brockden-Brown, Charles. Wieland \& Memoirs of Carwin the Biloquist. Oxford, NY: Oxford UP, 1998. Print.

Brockden-Brown, Charles. Edgar Huntly or Memoirs of a Sleepwalker. Kent, Ohio: Kent State UP, 1984. Print.

Brooks, Peter. Reading for the Plot: Design and Intention in Narrative. Cambridge, MA: Harvard UP, 1992. Print.

Cody, Michael. Charles Brockden Brown and the Literary Magazine. Jefferson, NC: McFarland \& Company, Inc., Publishers, 2004. Print.

Derrida, Jacques, and Gil Anidjar. Acts of Religion. New York: Routledge, 2002. Print.

Elbert, Monika "The Paradox of Catholicism in New England Women's Gothic" Transnational Gothic: Literary and Social Exchanges in the Long Nineteenth Century Ed. Monika Elbert and Bridget Marshall. Burlington, VT: Ashgate, 2012. (113-139) Print.

Galluzzo, Anthony. “Charles Brockden Brown's Wieland and the Aesthetics of Terror: Revolution, Reaction, and the Radical Enlightenment in Early American Letters” Eighteenth-Century Studies 42.2.Winter (2009): 60-88. Print.

Gilmore, Michael T. "Calvinism and Gothicism: The Example of Brown's Wieland” Studies in the Novel 9.2 Summer (1977): 107-119. Print.

"Gothic, adj. and n." OED Online. Oxford University Press, June 2014. Web. 25 August 2014.

Hughes, Robert. Philosophy, Psychoanalysis, Literature : Ethics, Aesthetics, and the Beyond of Language. Albany, NY: SUNY Press, 2011. Print.

Koenigs, Thomas. "'Whatever May Be the Merit of My Book as Fiction': Wieland's Instructional Fictionality” ELH 79.3 Fall (2012): 715-745. Print.

Levinas, Emmanuel. Totality and Infinity: An Essay on Exteriority. The Hague: M. Nijhoff, 1979. Print.

Nichols, Marcia. "Cicero's Pro Cluentio and the 'Mazy' Rhetorical Strategies of Wieland” Law and Literature 20.3.Fall (2008): 459-476. Print.

Russo, James R. "'The Chimeras of the Brain': Clara's Narrative in 'Wieland"' Early American Literature 16.1 (1981): 60-88. Print.

Surratt, Marshall. “'The Awe-Creating Presence of the Deity': Some Religious Sources for Brockden Brown's Wieland” Papers on Language and Literature 33.3 (1997): 310-324. Print

Tomkins, Jane. Sensational Designs: The Cultural Work of American Fiction, 17901860. Oxford, NY: Oxford UP, 1986. Print

Todorov, Tzvetan. The Fantastic: A Structural Approach to a Literary Genre. Ithaca, 
NY: Cornell UP, 1975. Print.

Verhoeven, W.M. "Gothic Logic: Charles Brockden Brown and the Science of Sensationalism” European Journal of American Culture 20.2 (2001): 91-99. Print

Wood, Gordon S. "Conspiracy and the Paranoid Style: Causality and Deceit in the Eighteenth-Century” The William and Mary Quarterly $3^{\text {rd }}$ Series 39.3 (1982): 401-441. Print 